Saudi Journal of Business and Management Studies Abbreviated Key Title: Saudi J Bus Manag Stud ISSN 2415-6663 (Print) |ISSN 2415-6671 (Online) Scholars Middle East Publishers, Dubai, United Arab Emirates Journal homepage: https://saudijournals.com/sibms

Original Research Article

\title{
Capital Market Reaction in Indonesia Stock Exchange to Stock Split Events Reviewed From Abnormal Returns, Trading Volume and Bid-Ask Spreads in Growing and Good Speaking Companies
}

Muhammad Nur Madani, Rusdiah Iskandar, Musdalifah Azis*

Mulawarnan University Indonesia

DOI: $10.36348 /$ sjbms.2020.v05i07.007

| Received: 08.07.2020 | Accepted: 16.07.2020 | Published: 21.07.2020

*Corresponding author: Musdalifah Azis

\section{Abstract}

This study aims to obtain empirical evidence and analyze differences in abnormal retruns, tranding volume, and bid-ask spreads on companies that grow and companies do not grow before and after the announcement of a stock split and to know the average abnormal retrun and average tranding volume stock and average daily bid-ask spread of share around stock split announcements. This study uses 66 companies listed on the Indonesia Stock Exchange which carried out a 2013-2019 stock split period. Companies grew to 48 companies and 18 companies did not grow. Categorizing cpmpany growth an growth using the ISO (Investment Opportunity Set) proxy MVE/BVE (Market Vakue For Equity Book) Proxy. Data Collection techniques in this study were carried out using a purposive sampling method base on secondary data availabel on the Indonesia Stock Exchane. The method of analysis use the Pried Test t-test sample, Wilcoxon Signed Rank Test and Multiple Regression with IBM SPSS version 22.This study shows that there are significant differnces in bid-ask spreads, friendly tranding volume in companies growing and not growing before and after the stock split, and there are significant abnormal retrun differnces in reef companies but there are not significant differences in companies not growing before and after a stock split and there is a significant influence of average abnormal retrun and the average trading volume of shares simultaneously on the average bid-ask spread around the annoucement of a stock split.

Keyword: Stock Split, Abnormal Retrun, Trading Volume, Bid-ask Spread, Growth and Ungrowth Company.

Copyright @ 2020: This is an open-access article distributed under the terms of the Creative Commons Attribution license which permits unrestricted use, distribution, and reproduction in any medium for non-commercial use (NonCommercial, or CC-BY-NC) provided the original author and source are credited.

\section{INTRODUCTION}

The capital market is a tool that brings investors as the owner of the funds with the company as the party who needs funds by trading securities. The capital market can create efficient fund allocations, because those who have excess funds can choose investment alternatives in the capital market in the hope of getting the most optimal rewards.

According to the capital market law No.8 of 1995 article 1 point 13 regarding the definition of the capital market is "Activities relating to public offerings and trading of securities". Companies use the capital market as a means to increase funding needs by issuing bonds or selling shares Azis, M (2015) [1]. Investors choose companies that are considered to be able to provide retruns that are in line with their expectations and companies that they consider to have high future earnings prospects. Information becomes a very important thing because an investor before investing funds in the capital market must first understand all information relating to capital market.

Information as explained above in something that is very important for investors who will invest their funds in the capital market. Information is a fundamental requirement for investors in making decisions related to portfolio selection with a certain level of risk. Information can also reduce the level of uncertainty that occurs, so that decisions taken in accordance with the objectives to be achieved. An information will be very useful if the information is able to cause investors to plunge in the capital market, this 
will be reflected in indicators or market characteristics such as stock prices trading volumes, stock returns.

The capital market is able to react quickly and accurately which will reflect the information needed immediately, so the capital market is called an efficient market. An efficient market, the market price of a security that is traded at all times always reflects all information generally known from that security. The effect of information on an efficient capital market is that prices will always adjust to new information as it arises. Information is considered informative if the information is able to change the confidence of decision makers.

Investors who transact in the capital market need information to make a decision in choosing a profitable investment portfolio. Information can reduce the uncertainty that occurs so that the decisions taken are expected to be in accordance with what is to be achieved. Issuers in the capital market have a variety of ways and techniques in increasing the liquidity of their companies such as the policy of conducting corporate actions such as stock split, reverse stock, dividend distribution, divestment (release) and rigts issue, there ere many things that can affect the company's management policy in the decision making process.

Sudana [2] an increase in nominal stock prices that are too high can cause a decrease in demand for the purchase of shares of the company and in the and can cause the company's stock prices to become static and no longer volatile. The decrease in the number of shares requests can be caused because not all investors are interested in buying shares at too high a price, especially individual investors who have a limited amount of funds, this can cause investors to switch to buying shares of other companies.

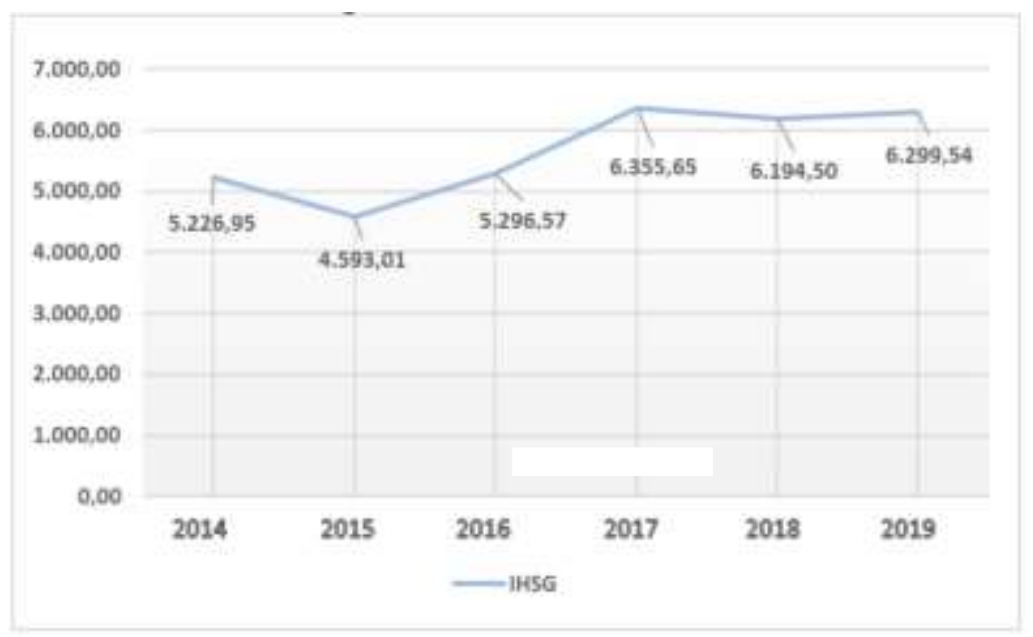

Fig-1: IHSG Movement From 2014-2019

(Source: Finance.yahoo.com)

Table -1: IHSG Movement From 2014-2019

\begin{tabular}{|c|c|c|}
\hline Year & IHSG Movement Level & IHSG Movement ( \% ) \\
\hline 2014 & $5.226,95$ & 22,29 \\
\hline 2015 & $4.593,01$ & $(12,13)$ \\
\hline 2016 & $5.296,57$ & 15,32 \\
\hline 2017 & $6.355,65$ & 19,99 \\
\hline 2018 & $6.194,50$ & $(2,53)$ \\
\hline 2019 & $6.299,54$ & 1,69 \\
\hline \multicolumn{3}{|c|}{ Source: finance.yahoo.com } \\
\hline
\end{tabular}

The strong foreign domination in the Indonesia capital market makes the IHSG movement easily affected by global economic events, as seen from table 1 and figure 1 shows that in 2015 it decreased by $12,13 \%$, in 2018 it fell $2,53 \%$ and in 2019 IHSG closed at level $1,69 \%$ compared to 2018, still strong foreign dominance in the at IHSG which is IDR 1.907 trillion or $51,46 \%$ of total equity while the proportion of domestic investors is IDR 1.799 trillion or $48,54 \%$, this causes the movement of IHSG is strongly influenced by foreign policies and global phenomena, such as the United States' central bank red funds (FFR) and
American and Chinese trade wars that have caused uncertain foreign exchange fluctuations from events that occurred from 2015 to 2019 where there is still strong foreign dominance in the IHSG which has greatly influenced movements IHSG.

Companies that avoid these conditions try to find solutions or maintain or strengthen company liquidity by carrying out corporate actions, namely stock split. Corporate action is a corporate action that is expected to influence the behavior of investor to invest in the company. Types of corporate actions such as: 
dividend distribution, divestment, right issue, stock split and reversal stock. One of the most common corporate actions taken by the company is the stock split.

A stock split is an act of a company going public to increase the number of shares outstanding, which is done when the stock price is overvalued, thereby reducing the ability of investors to buy it. Announcement of stock split becomes significant information by investors in decision making, this will lead to increased demand for shares and shares will become more liquid.

Melati \& Nurwulandari [3] Signaling theory states that a stock split is a good signal given by the company to the public relating to the company's prospects in the future. Managers will only split stocks if they are optimistic that future shares will increase, or at least not reduce, if managers believe that future share prices will decline, they will not be willing to split stocks because of rising share trading costs at lower prices, said Another stock split in considered as a signal given by management that the company has good prospects in the future.

Trading range theory provides an explanation that stock split increases the value of stock liquidity. According to Baker and Powell [4] The main motive in breaking stock in moving prices into a better trading range, followed by increasing liquidity and signals of optimistic expectations about the future. Smaller nominal shares will make individual investors who have limited funds be more interested, especially for domestic investors, the more domestic investors then the company, the less the risk of being affected by global events.

The stock split event makes the stock split lower so it is easier to reach by small investors, this will lead to increased stock demand and become more liquid. Stock split gives a positive signal because company managers will convey good future goals from the company to the public who do not know it yet, this is related to how quickly information is absorbed by the market which is reflected in the theory of efficient markets in adjusting towards new equilibrium prices. According to Jogiyanto [5]. Efficient market is a fast and accurate market reaction to achieve a new balance that fully reflects the available information.

The availability of information on an event is related to the (Efficient Market Hypothesis Theory) which states that the stock price formed is a reflection of all available information Jogiyanto [5]. This efficient market hypothesis theory is a major reference for Investors in making decisions in the capital market, because investors assume that the information presented both from the internal company and from outside the company is true.
Stock split is done because the stock price is too high so that the stock is not liquid, if the stock is not liquid the fewer stock trades. Slight transactions cause price to not fluctuate so that to obtain an abnormal return is also less [6]. The purpose of investors investing is to get a return. Returns are the results obtained from investments, can be realized returns or can be expected retruns that have not yet occurred but are expected to occur in the future. The difference between the actual retrun and the expected return is referred to as abnormal return Wistawan \& Widanaputra [7]. On the other hand, a stock split is considered a positive signal because the company's managers will convey good future prospects. The reason for this signal is supported by the company that issued the stock split is a company that has good performance. Because stock split contains costs that must be borne, only companies that have good prospects are able to bear these costs and as a result the market will react positively Hartono [1].

\section{LITERATURE REVIEW Signaling Theory}

Signal theory was first put forward by Ross [8], who explained that a good financial statement is a signal or a sign that the company's performance is in good condition. This will later be conveyed by company managers to company owners and external parties because of the asymmetric information that the company (manager) knows more about the company's future prospects compared to the owner or external parties (investors)

\section{Trading Range Theory}

According to Baker and Powell [4]. The main motive of stock split is moving prices into a batter trading range, followed by increasing liquidity and signals of optimistic expectations about the future. Trading Range Theory states that a stock split will increase stock trading liquidity. Stock split makes stock prices affordable by all investors to transact so as to increase stock liquidity [7].

\section{Efficient Market Hypothesis}

Fama [9] provides an understanding that the concept of an efficient market means that current stock prices reflect all available information. This means that information is good from past, present and added information from the company itself (insider information). This efficient market hypothesis theory is a main reference for investors in making decisions on the capital market, because investors assume that the information presented both from internal and external companies is true.

\section{Stock Split}

Jogiyanto [5] stock split is breakingup a sheet of shares into $\mathrm{n}$ shares. The price per new share after a stock split is $1 / \mathrm{n}$ from the previous price. Thus, stock split does not actually add value to a company or do not 
have economic value. According to Riyadi, S., Andrefa [10] stock splitting is an activity carried out by the company in order to increase the number of outstanding shares to become more numerous. Basically there are two types of stock split that can be done, namely split up and split down ( reverse split). An upward split is an increase in the number of shares outstanding by breaking up a single share of stock into $\mathrm{n}$ shares, while a downward split is the opposite of an upside breaking, which in increasing the nominal value per share by reducing the number of shares outstanding.

\section{Event Study}

Even study is a study that studies the market reaction to an event which later information from research this event study will be published as an announcement Hartono [1] Even Study can be used to test the information content of an announcement and can also be used to test masket efficiency forms a strong half. Event studies allow measuring the impact of certain events on a particular company's market value.

\section{Abnormal Return}

Lasmanah \& Bagja [11] abnormal return is the difference between the actual return and expected return that can occur before the information is published, or there has been a leak of information after the official information is published. According to Hartono [1] abnormal return is an excess of returns that actually occur against normal returns. Normal returns are expected returns (returns expected by investors). Thus, Abnormal Return (AR) is the difference between the actual return that occurs with the expected return.

$$
\mathrm{AR}_{\mathrm{i}, \mathrm{t}}=\mathrm{R}_{\mathrm{i}, \mathrm{t}}-\mathrm{E}\left(\mathrm{R}_{\mathrm{i}, \mathrm{t}}\right)
$$

AR i,t : abnormal return of securities $i$ in the $t$-th event period

$\mathrm{Ri,t}$ : return realization that ocured for the isecurities in the t-event period

$E(\mathrm{Ri}, \mathrm{t})$ : return expectation of the $\mathrm{i}$ security for the $t$ event

Realized return or return is actually the benefit obtained from stock investment in a certain period, the difference in current prices is realitive to the previous price. Can be calculated using the formula:

$$
\mathrm{R}_{\mathrm{i}, \mathrm{t}}=\frac{P_{i, t}-P_{i, t}-1}{P_{i, t}-1}
$$

\section{Information}

$\mathrm{R}_{\mathrm{i}, \mathrm{t}} \quad$ : actual return or stock return $\mathrm{i}$ on the $\mathrm{i}$-day

$\mathrm{P}_{\mathrm{i}, \mathrm{t}} \quad$ : i stock price on the t-day

$\mathrm{P}_{\mathrm{i}, \mathrm{t}} \mathrm{t}^{-1} \quad$ : i stock price on day $\mathrm{t}-1$

$\mathrm{E}\left(\mathrm{R}_{\mathrm{i}, \mathrm{t}}\right)=\mathrm{RM}, \mathrm{t}$

\section{Information}

$E\left(R_{i, t}\right)$ : Return of $i-t h$ securities expectations in the $t-$ event period.
$\mathrm{RM}, \mathrm{t} \quad$ : Return of the security at time $\mathrm{t}$.

How to calculate the formula RM, $\mathrm{t}$

$$
\mathrm{RM}, \mathrm{t}=\frac{I H S G_{i, t}-I H S G_{i, t}-1}{I H S G_{i, t}-1}
$$

\section{Information}

RMt : Return of the security at time $t$.

IHSG : Composite stock price index for the t-day

IHSG t-1 : Composite stock price index to $\mathrm{t}-1$

\section{Stock Trading Volume (Trading Volume Activity)}

The volume of stock trading is a picture of the condition of securities traded on the capital market. Imelda, Siregar, \& Anggraeni [12]. TVA'S trading volume activity illustrates the ratio between the number of shares traded and the number of shares traded and the number of shares outstanding in a certain period. Dalimunthe [13]. TVA is an equation that shows the value of the comparison between the numberof shares traded in a certain time with the number of shares outstanding at a certain time. Themore often a stock is traded, the trading volume of the company's shares is also getting bigger.

$$
\mathrm{TVA}_{\mathrm{it}}=\frac{\text { Stocks } \text { traded at } \text { time }_{t}}{\text { Stock }{\text { i outstanding at } \text { time }_{t}}_{\text {out }}}
$$

Where :

$\mathrm{TVA}_{\mathrm{it}}=$ Activity of trading volume of company $\mathrm{i}$ shares over a period of time $t$.

\section{Spread Theory}

Bid-ask spread is defined as the difference between the price offered to sell (ask of offer price) with the price asked to buy (bid price) with the price offered to sell ( ask or offer price). Mardiyati, Rachmatullah \& Ahmad [14] Bid-ask spread is an instrument that can be used to see the capital market's reaction to information through the parameter difference or the difference between the highest price requested to buy with the lowest price offered to sell.

Information:

$$
\text { Spread }_{\mathrm{i}, \mathrm{t}}=\frac{\left(a s k_{t}-b i d_{t}\right)}{\frac{\left(a s k_{t}+b i d_{t}\right)}{2}}
$$

Bid-ask spread $=$ value of price difference and selling interest rate

$\mathrm{Bid}_{\mathrm{i}, \mathrm{t}} \quad=$ price of shares bought with interest i closing period $\mathrm{t}$

$\mathrm{Ask}_{\mathrm{i}, \mathrm{t}}=$ the stock price of interest on the saleof the closing period $\mathrm{t}$

\section{Company Growth}

Go public companies can be catagorized as large companies or companies that have better growth, so that company growth can affect the value of the company. Investors will be more interested in large companies than small companies. Hidayah [15] Investment Opportunity Set (IOS) is a choice of future investment opportunities that can affect the growth of 
company or project assets that have a positive net present value. Yenny Wulansari [16] Investment opportunity set describes the extent of investment opportunities for a company for the benefit of the future.

$$
\mathrm{MVE} / \mathrm{BVE}=\frac{\text { outstanding shares } x \text { closing stock prices }}{\text { total equity }}
$$

Information :

a. MVEBVE < 1, the company is classified as a company does not grow

b. MVEBVE > 1, vice versa, companies are classified as gowing companies.

\section{Bid-Ask Spread Companies Grow Before and After Stock Split}

Janiantari \& Badera [17] stated the bid-ask spread is the difference in the price of buying or selling at a certain time. The distance or the difference between the buying and selling prices is an indication of market liquidity which means that if the spread decreases the higher the liquidity of the market at that time.

Hypothesis I : There is a significant bid-ask spread difference for companies to grow before and after a stock split.

\section{Company Bid-Ask Spread Does Not Grow Before and After Stock Split}

A, Nur \& Montazeri [18], bid-ask spread is the diffrence between the lowest bid price and the highest purchase price at the end of tranding hours for a type of stock on the IDX. If the bid-ask spread of a stock is lower, this shows that the level of liquidity of the stock is increasing.

Hypothesis Il : There is a significant bis-ask spread difference in companies that do not grow before and after the stock split

\section{The Trading Volume of Shares in a Company Grew} Up Before and After the Stock Split

Sakti \& Rini [19] states that the development of stock trading volume reflects the strength between demand and supply which is a manifestation of investor behavior. The greater liquidity value indicates that the shares are more liquid.

Hypothesis lll: There are significant differences in stock trading volume in companies that grow before and after a stock split.

\section{The Trading Volume of Shares in Companies Does} Not Grow Before and After Stock Split

Surya [20] states that the volume of stock trading. Trading activities in a very high volume on an exchange will be interpreted as sign that the masket will improve (bullish). The increase in trading volume is an increase in investors buying and selling activities on the stock exchange.
Hypothesis IV: There are significant differences in stock trading volume in companies that do not grow before and after the stock split.

\section{Abnormal Returns on Firms Growing Before and After Stock Split \\ Pamungkas [21] states that abnormal returns} are an excess of returns that actually occur againts normal returns. Normal return is the expected return ( the return expected by the investor). Thus the abnormal return shows the difference between the actual return that occurs with the expected return.

Hypothesis V: There is a significant difference in abnormal returns for companies to grow before and after a stock split.

\section{Abnormal Returns on Companies Not Growing Before and After Stock Split \\ Dalimunthe [13] states that a positive} abnormal return indicates that the return received is greater than the expected return, conversely if the return received is smaller than expected then it is called a negative abnormal return. Abnormal return can be positive or negative, if there are no events, the actual return tendsnot to differ from expected returns, but conversely if there is an event that is likely to cause changes in cash flow in the future, the market will react to the announcement so that the actual return will be different from the expected return.

Hypothesis Vl: There is a significant difference in abnormal returns in the company does not grow before and after the stock split.

Average Abnormal Returns and Average Stock Trading Volume Around Stock Split Announcements Agains Avarage Bid-Ask Spread Around Stock Split Announcements.

Surya [20] High stock prices provide high returns indicating that the stock is favored by investors. When the stock price is high, it means that the stock is actively traded, so the dealer will not keep the stock for too long. Thiswill have an impact on the level of bid ask spread and decreased cost of ownership, which in turn leads to higher stock prices, the smaller the bid ask spread the large trading volume shows that the stock is favored by investors which means that the stock is quickly traded. Trading volume will reduce the shareholding cost there by reducing spread. Thus the more active trading of a stock or the greater the trading volume of a stock, the lower the costof ownership of the stock which means it will narrow the bid-ask spread of the stock.

Hypothesis Vll: There is significant influence on the average abnormal return and the average stock trading volume around the announcement of stock split on the average bid-ask spread around the announcement of stock split. 


\section{Conceptual Frameworks}

The conceptual framework in this study can be described as follows:

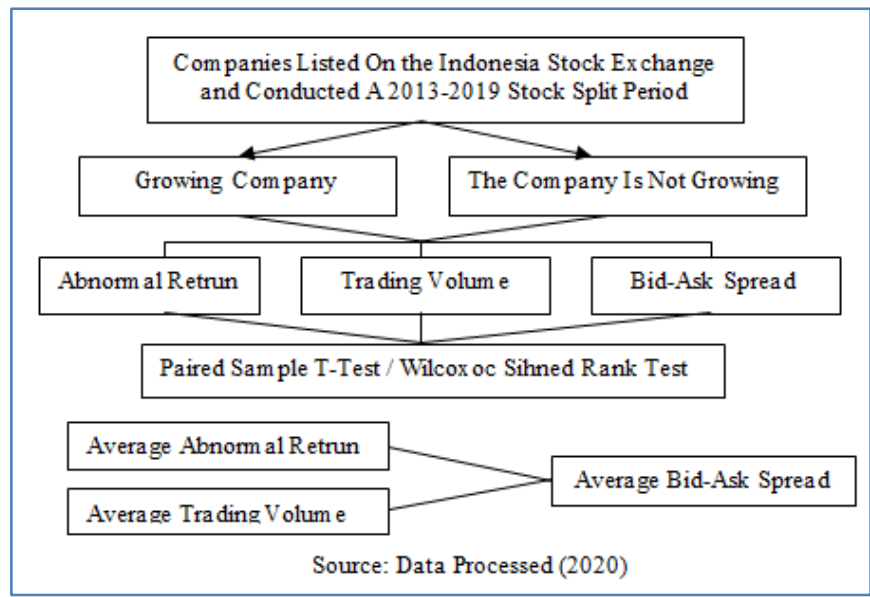

\section{METHODOLOGY}

The population in this study are all companies listed on the indonesia Stock Exchange and conducted a stock split during the period 2013-2019. The sampling technique uses a puposive sampling method which is the method of responding to be sampled based on certain criteria, i.e. the company was listed on the Indonesia Stock Exchange in 2013 to 2019 and published a yearly report, the company conducted a stock splite in the period 2013 to 2019, the sample company had all the necessary data. So that the final sample in this study was a gowing company 48 companies and 18 companies did not grow. The data used are secondary data obtained from the official website www.idx.co.id that is the annual report of each company.

\section{Variable Measurement}

A summary of the measurements of each research variable is summarized in table 2 as follows :

Table-2: Variable Measurement

\begin{tabular}{|l|l|}
\hline \multicolumn{1}{|c|}{ Variabel } & \multicolumn{1}{c|}{ Metode kalkulasi } \\
\hline Stock Split & Stock Split $=$ Old Stock $\div$ New Stock \\
\hline Bid-Ask Spread & Spread $=\frac{\left(a s k_{t}-\text { bid } t\right)}{\frac{\left(a s k_{t}+\text { bid } t\right)}{2}}$ \\
\hline Trading Volume & $\mathrm{TVA}_{\mathrm{it}}=\frac{\text { stock traded at time } t}{\text { stock } \text { i outstanding at time } t}$ \\
\hline Abnormal Retrun & $\mathrm{AR}_{\mathrm{i}, \mathrm{t}}=\mathrm{R}_{\mathrm{i}, \mathrm{t}}-\mathrm{E}\left(\mathrm{R}_{\mathrm{i}, \mathrm{t}}\right)$ \\
\hline Company Growth & $\mathrm{MVE} / \mathrm{BVE}=\frac{\text { outstanding shares } x \text { closing stock prices }}{\text { total } \text { ekuity }}$ \\
\hline
\end{tabular}

Source: Data Processed (2020)

\section{PRODUCT AND DISCUSSION}

\section{Test for Normality}

The normality test in this study uses the kolmogorov-smirnof (K-S) and shapiro-Wilk non- parametric test. In this test, if the probality value $>0.05$, then the data is normally distributed, but if the probality value $<0.05$, then the data is not normal.

Table-3: Kolmogorov-Smirnov Data Normality Test

\begin{tabular}{|c|c|c|}
\hline Variabel & Signifikansi & Information \\
\hline \multicolumn{3}{|l|}{ Growing Company } \\
\hline Bis-Ask Spread Before Stock Split & 0.070 & Normal \\
\hline Bid-Ask Spread After Stock Split & 0.298 & Normal \\
\hline TVA Before Stock Split & 0.000 & Not Normal \\
\hline TVA After Stock Split & 0.000 & Not Normal \\
\hline Abnormal Retrun Before Stock Split & 0.052 & Normal \\
\hline Abnormal Retrun After Stok Split & 0.200 & Normal \\
\hline \multicolumn{3}{|c|}{ Average Abnormal Return, TVA, and Bid-Ask Spread } \\
\hline $\begin{array}{l}\text { Abnormal Retrun, TVA, dan Bid-Ask Spread } \\
\text { (Understandardized Residual) }\end{array}$ & 0.200 & Normal \\
\hline
\end{tabular}

Source: Data Processed (2020) 
Table 4 : Shapiro-Wilk Data Normality Test

\begin{tabular}{|c|c|c|}
\hline Variabel & Signifikansi & Information \\
\hline \multicolumn{3}{|l|}{ Company Not Grow } \\
\hline Bis-Ask Spread Before Stock Split & 0.311 & Normal \\
\hline Bid-Ask Spread After Stock Split & 0.281 & Normal \\
\hline TVA Before Stock Split & 0.000 & Not Normal \\
\hline TVA After Stock Split & 0.000 & Not Normal \\
\hline Abnormal Retrun Before Stock Split & 0.082 & Normal \\
\hline Abnormal Retrun After Stock Split & 0.614 & Normal \\
\hline
\end{tabular}

Source: Data Processed (2020)

From Tables 3 and 4 it can be seen that the results of the normality test on the bid-ask spread variable, abnormal retrun before and after the stock split in growing and not growing companies show a significant value of more than 0.05 which means the data is normally distributed. Significant value in the stock trading volume variable indicates a value smaller than 0.05 which means that thedata is not normally distributed. For normally distributed data parametric tests can be performed and for non-normally distributed data non-parametric tests will be conducted.

\section{Heteroscedasticity Test}

Heteroscedasticity Test one of the important assumptions of the classic linear regression model is that the variance of the residuals that appear in the regression function is homoscedastic, there is a variance similarity from the residuals of one observation to another.

Table-5 : Heteroscedasticity Test

\begin{tabular}{|c|r|r|r|r|r|}
\hline \multirow{2}{*}{ Model } & \multicolumn{2}{|c|}{ Unstandardized Coefficients } & Standardized Coefficients & \multirow{2}{*}{ sig } & \\
\cline { 2 - 4 } & \multicolumn{1}{|c|}{ B } & Std. Error & Beta & & \\
\hline 1.(Constant) Abnormal Retrun TVA & .017 & .011 & .936 & .000 \\
& .027 & .087 & .305 & .761 \\
& -.222 & .266 & -.105 & -.836 & .406 \\
\hline
\end{tabular}

Source : Output SPSS (2020)

Based on table 5 above it is known that the results of the heteroscedasticity test indicate the significance value of each variable is greater than 0.05 . This shows that there was no heteroscedasticity in the regression model.

\section{Autocorrelation Test}

Autocorrelation test is a test conducted to see wether there is a correlation between a period $t$ with the previous period $(\mathrm{t}-1)$. The autocorrelation test in this study used the Durbin Watson test.

Table-6: Durbin Watson Test

\begin{tabular}{|c|c|c|c|c|c|}
\hline Model & R & R Square & Adjusted R Square & Std. Error of the Estimate & Durbin-Watson \\
\hline 1 & .334 & .111 & .083 & .1279066897 & 1.832 \\
\hline
\end{tabular}

a. Predictor: (Constant),X2,X1

b. Dependent Variable : Y

Souce: SPSS (2020)

Based on the table 5.6 of the test result, the DW test score of 1.832 is greater than du (1.6640) and smaller than the 4 -du value $(2.4603)$ or $(1.6640<$ $1,832<2.4603)$, so it can be concluded that there is no autocorrelation in the model used in this study.

\section{Multicollinearity Test}

Multicollinearity test aims to the test whether a regression model has a correlation between independent variables.

Table-7: Multicollinearity Test

\begin{tabular}{|l|c|c|c|c|c|c|c|}
\hline \multirow{2}{*}{ Model } & \multicolumn{2}{|c|}{$\begin{array}{c}\text { Unstandardized } \\
\text { Coefficients }\end{array}$} & $\begin{array}{c}\text { Standardized } \\
\text { Coefficients }\end{array}$ & \multirow{2}{*}{$\begin{array}{c}\text { S } \\
\text { Sig. }\end{array}$} & \multicolumn{2}{c|}{$\begin{array}{c}\text { Collinearity } \\
\text { Statistics }\end{array}$} \\
\cline { 2 - 4 } \cline { 5 - 7 } & $\mathbf{B}$ & Std. Error & Beta & & & Tolerance & VIF \\
\hline 1. (Constant) & .132 & .019 & .180 & 7.026 & .000 & .989 & 1.011 \\
Abnormal Retrun (X1) & .230 & .153 & .300 & 1.506 & .137 & .989 & 1.011 \\
TVA (X2) & 1.173 & .466 & & 2.516 & .014 & & \\
\hline
\end{tabular}

Source: SPSS (2020) 
Based on table 7 above, it is known that the VIF value of each independent variable is below 10 and tolerance is greater than 0.10 . This shows that there is no correlation between independent variables. So it can be concluded that the regression model used in this study did not occur multicollinearity.

\section{Regression analysis}

The result of hypothesis testing are multiple linear regression models the influence of the average abnormal retrun, the average trade volume to the average bid-ask spread and the hypothesis testing with the simple linear regression model of the influence of the abnormal retrun, Trade Volume, bid-ask spread before and after stock split in companies grow and not grow.

Table-8: One Sample T-Test Test Table

\begin{tabular}{|c|c|c|c|c|c|}
\hline Testing & Mean & $\begin{array}{c}\text { Std. Error } \\
\text { Mean }\end{array}$ & $\begin{array}{c}\mathrm{t}- \\
\text { Statistic }\end{array}$ & Prob. & Information \\
\hline \multicolumn{6}{|l|}{ Growing Company } \\
\hline Bid-Ask Spread Before and After a Stock Split & -0.092749 & 0.020277 & -4.574 & 0.000 & Significant \\
\hline Abnormal Retrun Before and After a Stock Split & 57.796618 & 25.842181 & 2.2365 & 0.030 & Significant \\
\hline \multicolumn{6}{|l|}{ Company Not Grow } \\
\hline Bid-Ask Spread Before and After a Stock Split & -0.745262 & 0.298684 & -2.495 & 0.023 & Significant \\
\hline Abnormal Retrun Before and After a Stock Split & 68.580625 & 34.422332 & 1.992 & 0.062 & Not Significant \\
\hline
\end{tabular}
Source: Output SPSS (2020)

Table-9: Wilcoxon Signed Rank Test

\begin{tabular}{|l|c|c|c|}
\hline \multicolumn{1}{|c|}{ Testing } & Z-Statistic & Prob. & Information \\
\hline Growing Company & -5.169 & 0.000 & Significant \\
\hline Trading Volume Before and After Stock Split & & \\
\hline Company Not Grow & -2.025 & 0.043 & Significant \\
\hline Trading Volume Before and After Stock Split &
\end{tabular}

Source: Output SPSS (2020)

From Tables 8 and 9 the test results obtained a significant value on the variable bid-ask spread, stock trading volume, abnormal retrun before and after the stock split in companies growing there are significant differences seen from significant values smaller than
0.05, whereas in abnormal retrun before and after the stocck split the company does not grow shows a significant value greater than 0.05 this shows there is no significant difference in abnormal retrun before and after the stock split in the company does not grow.

Table-10: ANOVA

\begin{tabular}{|c|l|c|c|}
\hline \multicolumn{1}{|c|}{ Testing } & F-Statistic & Prob. & Information \\
\hline $\begin{array}{l}\text { Abnormal retrun and stock trading volume against } \\
\text { the bid-ask spread around stock split announcements. }\end{array}$ & 3.942 & 0.024 & Significant \\
\hline
\end{tabular}
Source: Output SPSS (2020)

From the result of the SPSS output in table 10 above it is obtained that the calculated F-value is 3.942 with a P-value of 0.024 which is greater than 0.05 . Because it is a hypothesis which states that there is a significant influence of the abnormal retrun average, the tading volume of shares around the announcement of a stock split against the average bid-ask spread around the announcement of a stock split.

\section{Based on table 10 above, the regression results can be interpreted as follows}

1. Significant value of bid-ask spreads in the company grows before and after the stock split shows a value of 0.000 . This value is smaller than the alpha level of $5 \%(0,000<0.05)$. This means that there is a significant bid-ask spread difference for companies to grow before and after a stock split.
2. Significant value of bid-ask spread on companies that do not grow before and after the stock split shows a value of 0.023 . This value is smaller than the alpha level of $5 \%(0.023<0.05)$. This means that there is a significant bid-ask spread difference for compannies that do not grow before and after a stock split.

3. Significant value of stock trading volume in companies growing before and after the stock split shows a value of 0.000 . This value is smaller than the alpha level of $5 \%(0.000<0.05)$. This means that there are significant differences in the stock trading volume of the company growing before and after the stock split.

4. Significant value of stock trading volume in companies that do not grow before and after the stock split shows a value of 0.043 . This value is smaller than the alpha level of $5 \%(0.043<0.05)$. 
This means that there are significant differences in the stock trading volume in companies that do not grow before and after a stock split.

5. Significantly abnormal retrun value of the company growing before and after the stock split shows a value of 0.023 . This value is smaller than the alpha level of $5 \%(0.023<0.05)$. It means that there is a significant abnormal retrun difference in a company that grows before and after a stock split.

6. Significant abnormal retrun on the company does not grow before and after the stock split shows a value of 0.062 . This value is greater than the alpha level of $5 \%(0.062>0.05)$. That is, that there is no significant abnormal retrun difference in accompany does not grow before and after the stock split.

7. Significant value of abnormal retrun average and average trading volume of the stock against the bidask spread around the announcement of the stock split shows a value of 0.024 . this value is smaller than the alpha level of $5 \%(0.024>0.05)$. This means that there is an influence of abnormal retrun average and average stock trading volume on the sifnificant bid-ask spread around the announcement of a stock split.

\section{CONCLUSION}

The results of the study prove that there is a significant difference in the bid-ask spread of the companyto grow and not grow, the trading volume of the company's stock grows and the company does not grow, abnormal retrun the company grows but there is no significant difference abnormal retrun in the company does not grow before and after the stock split and there is a significant influence from the average abnormal retrun and the average trading volume of shares on the average bid-ask spread around the announcement of a stock split.

The results of this study are expected to be used as a basis for investors' analysis before investing to pay attention to information provided by the market so that investment decisions to be taken are not wrong and have a good impact on investors. And for further researchers, it is hoped that they will be able to test other variables that can be influenced by stock split announcements made by companies, such as dividends and profits. In addition, the company categorizes using IOS proxies based on other prices such as Tobin'q, the ratio of value to book value of PPE, and the ratio of value to depreciation expense as well as proxy based on investment or variance.

\section{REFFERENCE}

1. Azis, M (2015). Manajemen Investasi : Fundamental, Teknikal, Perilaku Investor, dan Return Saham, Ed1, Deepublish, Yogyakarta

2. Sudana, I. M. (2015). Teori \& Praktik Manajemen Keungan Perusahaan (Edisi 2; N. I. Sallama, ed). Jakarta: Erlangga
3. Melati, M., \& Nurwulandari, A. (2017). Analisis Reaksi Pasar Terhadap Corporate Action Pada Perusahaan Bertumbuh Dan Tidak Bertumbuh Di Bursa Efek Indonesia. Oikonomia 13(2) - Melati Dan Nurwulandari, 13(2), 1-25.

4. Baker, H., Powell, G. (1993). Furher evidence on managerial motive for stock split. Quarely jurnal of business and economic, 32(3), 20-31

5. Jogiyanto, H. (2015). Teori Portofolio dan Analisis Investasi (Edisi Kesepuluh). Yogyakarta: BPFEYogyakarta.

6. Utami, D. P., \& Asandimitra, N. (2017). Analisis Of Abnormal Retrun, Tranding Volume, And BidAsk Spread At The Period Of Stock Split Announcement. IOSR Jurnal Of Economics And Finance, 08(04), 83-93

7. Wistawan, I. M. A. P., \& Widanaputra, A. A. G. P. (2013). Dampak Pengumuman Pemecahan Saham Pada Perbedaan Abnormal Retrun. E-Jurnal Akuntansi Universitas Udayana, 1, 1-16

8. Ross, S. A. (1977). Determination of Financial Structure: The Incentive-Signalling Approach. Bell $\mathrm{J}$ Econ. The Bell Jurnal of aconomics, 8(1), 23-40

9. Fama, E. F. (1970). Efficient capital markets: A review of theory and empirical work. The journal of Finance, 25(2), 383-417.

10. Riyadi, S., Andrefa, S. (2013). Analisis Dampak Stock Split Terhadap Harga, Volume Dan Keputusan Investasi Pada Saham. E-Jurnal Manajemen Dan Bisnis

11. Lasmanah., \& Bagja, B. (2014). Abnormal Retrun And Stock Trading Volume Analiysis On The Company Taking Stock Split At Indonesia Stock Exchange Period 2010-2013. International jurnal of science nad research, 2(4), 566-572

12. Imelda, I., Siregar, H., \& Anggraeni, L. (2015). Abnormal Retrun and Tranding Volume in the Indonesia Stock Market in Relation to the Presidential Elections in 2004, 2009, and 2014. Bisnis \& Birokrasi Jurnal, 21(2)

13. Dalimunthe, T. (2015). Analisis Pengaruh Stock Split Terhadap Saham, Volume Perdagangan Dan Abnormal Retruan Pada Perusahaan Bertumbuh Dan Tidak Bertumbuh, Jurnal Online Mahasiswa Fakultas Ekonomi Universitas Riau

14. Mardiyati, U., Rachmattullah, R., \& Ahmad, G. N. (2017). The Analysis of Abnormal Return, Liquidity And Stock Risk Difference During Pre And Post Stock Split In Idx Period 2010 Â€"2014. JRMSI-Jurnal Riset Manajemen Sains Indonesia, 8(1), 20-38.

15. Hidayat, N. (2015). Pengaruh Investasi Opportunity Set (IOS) Dan Kepemilikan Manajerial Terrhadap Nilai Perusahaan Pada Perusahaan Property Dan Real Estat Di Bursa Efek Indonesia. Jurnal Akuntansi, 19(3), 420 .

16. Wulansari, Y. (2013). Pengaruh Investment Opportunity Set, likuiditas dan leverage terhadap kualitas laba pada perusahaan manufaktur yang terdaftar di BEI. Jurnal Akuntansi, 1(2). 
17. Janiantari, I. G. A., \& Badera, I. D. N. (2014). Analisis Perbedaan Bid-Ask Spread Dan Abnormal Retrun Saham Sebagai Dampak Dari Pengumuman Stock Split. E-Jurnal Akuntansi, 8(2), 267-282.

18. Al Azhar, A., DP, E. N., \& Montazeri, M. A. (2014). Analisis Abnormal Return Saham, Volume Perdagangan Saham, Likuiditas Saham, Dan Variabilitas Tingkat Keuntungan Saham Sebelum Dan Sesudah Stock Split. Jurnal Akuntansi (Media Riset Akuntansi \& Keuangan), 2(1), 36-47.

19. Sakit, P. O., \& Rini, I. (2013). Analisis Pengaruh Stock Split Terhadap Abnormal Retrun Dan Volume Perdagangan Saham Pada Perusahaan Bertumbuh Dan Tidak Bertumbuh (Studi Kasus
Pada Bursa Efek Indonesia 2008-2012).

Diponogoro Jurnal Of Management, 2(3), 1-13

20. Surya, K. (2016). Pengaruh Harga Saham, Volume Perdagangan, Market Value Dan Varian Return Terhadap Bid-Ask Spread (Studi Empiris Pada Perusahaan Yang Terdaftar Efek Syariah). E-Jurnal Universitas Muhammadiyah Yogyakarta, 1(1), 1-15

21. Pamungkas, A. (2015). Pengaruh Pemilu Presiden Indonesia Tahun 2014 Terhadap Abnormal Retrun Dan Tranding Volume Activity (Study Pada Perusahaan Pada Perusahaan Yang Tercatat Sebagai Anggota Indeks Kompas100). Jurnal Administrasi Bisnis Univesitas Brawijaya, 21(2). 